\title{
Obstetric Cortical Renal Necrosis, Even Reality in the Tropics
}

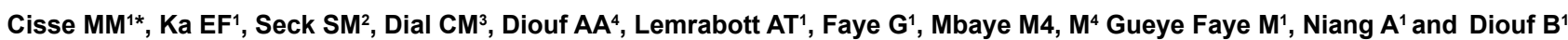

${ }^{1}$ Nephrology department of teaching hospital Aristide Le Dantec Dakar, Senegal

${ }^{2}$ Nephrology department of teaching hospital Gaston Berger Saint Louis, Senegal

${ }^{3}$ Pathology department of teaching hospital Grand Yoff Dakar, Senegal

${ }^{4}$ Obstetric and Gynecology department of teaching hospital Aristide Le Dantec Dakar, Senegal

\begin{abstract}
Obstetric cortical renal necrosis is a serious complication that can lead to chronic renal failure and the need for dialysis for life in some cases. In Africa, despite progress, much remains to provide in order to prevent this complication. Difficulties in health care access and lack of monitoring of pregnancies are contributing factors. We propose through 5 cases report the characteristics of obstetric renal cortical necrosis in the tropics.
\end{abstract}

Keywords: Cortical renal necrosis; Pregnancy; Senegal

\section{Introduction}

Cortical renal necrosis CRN is defined by a bilateral ischemic necrosis of the renal cortex without medullar lesion. It is a rare cause of acute kidney injury and it is mostly related to obstetrical causes [1]. Despite recent therapeutic progress, CRN is still associated with a high mortality of $19 \%$ and persistance residual renal impairment in $68 \%$ of cases [1]. There are very few data on prevalence and prognosis of CRN in Senegal. In this study, we report epidemiological, clinical and Para clinical patterns of five obstetrical cortical renal necrosis in Aristide Le Dantec Hospital of Dakar.

\section{Patients and Method}

We performed a retrospective analysis of 5 cases followed in Arstide Le Dantec Hospital between November 2009 and October 2012. Cortical renal necrosis was confirmed by renal biopsy that was performed after 21 days of therapy without recovery of renal function. Only histological samples with at least 8 glomerula were included in the study.

\section{Results}

The average age of our five patients was 33 years ranges from 25 to 40 years. All patients were received late in nephrology department with an average referral delay of 14 days. Clinical and Para clinical characteristics of each patient at admission are presented in Table 1. All patients had high blood pressure. Three patients had anuria cases 2 , 4 and 5, one oliguria case 3 and one normal diuresis case 1 . The mean serum creatinin and hemoglobin levels were $14.8 \mathrm{mg} / \mathrm{dL}$ and $6.4 \mathrm{~g} /$ $\mathrm{dL}$ respectively. All patients received hemodialysis treatment. Table 2 summarizes the therapeutic management of patients and their clinical evolution.

\section{Discussion}

Cortical renal necrosis is a rare cause of acute kidney injury in developed countries where incidence has dramatically decreased (Figure 1). It represents 1 to $2 \%$ of all causes of parenchymal acute kidney injury AKI [2]. Conversely, this incidence is still high around $6-7 \%$ in poor countries where quality of care is low [2]. Early studies from India found that renal cortical necrosis was responsible of 7.1\% dialysis for AKI [3]. However, more recent data showed lower prevalence of $3.8 \%$ and $4.6 \%$ in 1994 and 2003 respectively [3,4]. In a recent analysis of 1822 cases of AKI during 22 years in Eastern India, Prakash et al. report a prevalence of $3.12 \%$ for cortical necrosis [3]. In a group of 46 women who underwent renal biopsy for AKI in Madrid, Liano and Pascual found only one cortical necrosis case $0.13 \%$ [3].
Obstetrical complications represent the most frequent etiologies of cortical necrosis with about 50 to $70 \%$ of cases [4,5]. Recently, a retrospective cohort of 224 cases of postpartum AKI in Senegal, Lemrabott found $3.12 \%$ of cortical CRN [6]. But this low prevalence could be explained by the absence of renal pathology in the first 8 years of the study. In Morocco, $96 \%$ of patients admitted for AKI were not monitored during pregnancy $[7,8]$. The lack of monitoring is part of prenatal circumstances often found in patients with obstetric acute renal failure [9]. Three of our patients had completed their prenatal visit.

The risk of CRN seems to be higher in late pregnancy and in the immediate postpartum period due to important changes in hemostasis in the third quarter and at the time of delivery. In India, septic abortion in the first trimester represents $78 \%$ of cases [3]. In this work, cortical necrosis had occurred in the third trimester in all patients but only one of them was secondary to abortion case 4 . Bleeding was constant in our series and the delivery date was done 3 times by vaginally case 2, 4 and 5 . In a series of 48 patients, $3266 \%$ had a postpartum hemorrhage and $2960.4 \%$ had undergone a cesarean section [10]. The average time reference was 14.6 days. Our time was longer than that found in India, which was 4.7 days [4].

The main symptom of RCN is anuria. Three of our five patients were anuric after childbirth cases 2, 4 and 5. The other 2 were oliguric cases 1, 3. Prakash had $78.9 \%$ of cases and $21.1 \%$ of anuria oliguria [3]. The duration of anuria may be correlated with the percentage of glomeruli affected. All patients were hypertensive at admission. Blood pressure tends to rise even in hypovolemic shock after partial restoration of flow [11]. Laboratory tests confirmed the renal failure in our patients with a mean serum creatinine of $148.5 \mathrm{mg} / \mathrm{l}$, with a range of 70.5 to $370 \mathrm{mg} / \mathrm{l}$ and a mean blood urea of $2.096 \mathrm{~g} / \mathrm{l}$, with a range of 3.07 to $1.47 \mathrm{~g} / \mathrm{l}$. If the cortical necrosis is associated with hemolytic uremic syndrome, a hyperreticulocytosis with schistocytes and anisocytosis is found with

*Corresponding author: Cisse MM, Nephrology department of teaching hospital Aristide Le Dantec Dakar, Senegal, Tel: 002217757388 09; E-mail: mhmcisse@yahoo.fr

Received December 21, 2013; Accepted March 22, 2014; Published March 27, 2014

Citation: Cisse MM, Ka EF, Seck SM, Dial CM, Diouf AA, et al. (2014) Obstetric Cortical Renal Necrosis, Even Reality in the Tropics. J Nephrol Ther 4: 156 doi:10.4172/2161-0959.1000156

Copyright: $\odot 2014$ Cisse MM, et al. This is an open-access article distributed under the terms of the Creative Commons Attribution License, which permits unrestricted use, distribution, and reproduction in any medium, provided the original author and source are credited. 
Citation: Cisse MM, Ka EF, Seck SM, Dial CM, Diouf AA, et al. (2014) Obstetric Cortical Renal Necrosis, Even Reality in the Tropics. J Nephrol Ther 4: 156. doi:10.4172/2161-0959.1000156

Page 2 of 4

\begin{tabular}{|c|c|c|c|c|c|}
\hline Data & Case 1 & Case 2 & Case 3 & Case 4 & Case 5 \\
\hline Age (years) & 40 & 32 & 30 & 25 & 38 \\
\hline Medical past & $\begin{array}{l}\text { abortion } \\
\text { preeclampsia }\end{array}$ & None & None & None & 2 abortions \\
\hline $\begin{array}{l}\text { Number of } \\
\text { pregnancies/ } \\
\text { deliveries }\end{array}$ & $5 / 4$ & $9 / 9$ & $5 / 5$ & $1 / 1$ & $7 / 5$ \\
\hline $\begin{array}{l}\text { Prenatal } \\
\text { care during } \\
\text { the last } \\
\text { pregnancy }\end{array}$ & Yes & No & Yes & No & Yes \\
\hline $\begin{array}{l}\text { Obstetrical } \\
\text { complication } \\
\text { during } \\
\text { the last } \\
\text { pregnancy }\end{array}$ & Retroplacentar hematoma & Retroplacentar hematoma & $\begin{array}{l}\text { Preeclampsia and } \\
\text { Retroplacentar hematoma }\end{array}$ & Delivery hemorrhage & $\begin{array}{l}\text { Preeclampsia and } \\
\text { Retroplacentar hematoma }\end{array}$ \\
\hline $\begin{array}{l}\text { Mode of } \\
\text { delivery }\end{array}$ & Cesarean section & Normal & Cesarean section & Normal & Normal \\
\hline $\begin{array}{l}\text { Blood } \\
\text { pressure } \\
(\mathrm{mmHg})\end{array}$ & $180 / 100$ & $150 / 80$ & $160 / 90$ & $170 / 80$ & $160 / 110$ \\
\hline $\begin{array}{l}\text { Urine output } \\
(\mathrm{mL} / 24 \mathrm{~h})\end{array}$ & 700 & $<300$ & 400 & $<300$ & $<300$ \\
\hline Biological & $\begin{array}{l}\text {-Serum creatinin: } 6.35 \mathrm{mg} / \mathrm{dL} \\
\text {-Hemoglobin level : } 2.9 \mathrm{~g} / \mathrm{dL} \\
\text {-Platelets: } 180,000 / \mathrm{mm}^{3} \\
\text {-Proteinuria: } 6.4 \mathrm{~g} / 24 \mathrm{~h}\end{array}$ & $\begin{array}{l}\text { - Serum creatinin: } 7.25 \mathrm{mg} / \mathrm{dL} \\
\text { - Hemoglobin level : } 8.5 \mathrm{~g} / \mathrm{dL} \\
\text {-Platelets: } 140,000 / \mathrm{mm}^{3} \\
\text {-Proteinuria: NA }\end{array}$ & $\begin{array}{l}\text { - Serum creatinin: } 13.2 \mathrm{mg} / \mathrm{L} \\
\text {-Hemoglobin level: } 4.9 \mathrm{~g} / \mathrm{dL} \\
\text {-Platelets: } 129,000 / \mathrm{mm}^{3} \\
\text {-Proteinuria: } 2 \mathrm{~g} / 24 \mathrm{~h}\end{array}$ & $\begin{array}{l}\text { - Serum creatinin: } 37.0 \mathrm{mg} / \mathrm{dL} \\
\text {-Hemoglobin level: } 4.7 \mathrm{~g} / \mathrm{dL} \\
\text {-Platelets : } 743,000 / \mathrm{mm}^{3} \\
\text {-Proteinuria: } 0.8 \mathrm{~g} / 24 \mathrm{~h}\end{array}$ & $\begin{array}{l}\text { - Serum creatinin:: } 7.0 \mathrm{mg} / \mathrm{dL} \\
\text {-Hemoglobin level: } 6.7 \mathrm{~g} / \mathrm{dL} \\
\text {-Platelets : } 78,000 / \mathrm{mm}^{3} \\
\text {-Proteinuria: NA }\end{array}$ \\
\hline $\begin{array}{l}\text { Renal } \\
\text { ultrasound }\end{array}$ & $\begin{array}{l}\text {-Right kidney: } 122 \mathrm{~mm} \text {; } \\
\text { hyperechogenic cortex. } \\
\text {-Left kidney: } 125 \mathrm{~mm} \text {; } \\
\text { hyperechogenic cortex }\end{array}$ & $\begin{array}{l}\text { - Right kidney: } 113 \mathrm{~mm} \text {; } \\
\text { hyperechogenic cortex. } \\
\text { - Left kidney: } 119 \mathrm{~mm} \text {; } \\
\text { hyperechogenic cortex }\end{array}$ & $\begin{array}{l}\text { - Right kidney: } 110 \mathrm{~mm} \text {; } \\
\text { hyperechogenic cortex. } \\
\text { - Left kidney: } 102 \mathrm{~mm} \text {; } \\
\text { hyperechogenic cortex }\end{array}$ & $\begin{array}{l}\text { - Right kidney: } 110 \mathrm{~mm} \text {; } \\
\text { hypoechogenic cortex. } \\
\text { - Left kidney: } 105 \mathrm{~mm} \text {; } \\
\text { hypoechogenic cortex }\end{array}$ & $\begin{array}{l}\text { - Right kidney: } 120 \mathrm{~mm} \text {; } \\
\text { hypoechogenic cortex. } \\
\text { - Left kidney: } 120 \mathrm{~mm} \text {; } \\
\text { hypoechogenic cortex. } \\
\text { (Figure 2) }\end{array}$ \\
\hline Histological & $\begin{array}{l}\text {-subtotal cortical necrosis } \\
\text { - focal and segmental } \\
\text { glomerulosclerosis } \\
\text { - tubular necrosis }\end{array}$ & $\begin{array}{l}\text { - subtotal cortical necrosis } \\
\text { - focal and segmental } \\
\text { glomerulosclerosis }\end{array}$ & $\begin{array}{l}\text { - complete cortical necrosis } \\
\text { - thrombotic microangiopathy } \\
\text { - tubular necrosis } \\
\text { (figure 1) }\end{array}$ & - subtotal cortical necrosis & $\begin{array}{l}\text { - subtotal cortical necrosis } \\
\text {-Diffuse interstitial fibrosis }\end{array}$ \\
\hline
\end{tabular}

Table 1: Summary of clinical and paraclinical findings admission.

\begin{tabular}{|l|l|l|l|l|}
\hline Data & Case 1 & Case 2 & Case 3 & Case 4 \\
\hline Transfusion & $\begin{array}{l}\text { Yes with packed blood } \\
\text { cell (7 units) }\end{array}$ & Yes with hole blood (3 units) & $\begin{array}{l}\text { Yes with hole blood (3 } \\
\text { units) }\end{array}$ & Yes with hole blood (5 units) \\
\hline $\begin{array}{l}\text { Short term } \\
\text { treatment }\end{array}$ & Hemodialysis & $\begin{array}{l}\text { Hemodialysis } \\
\text { Frusemide } \\
\text { Nicardipine }\end{array}$ & $\begin{array}{l}\text { Hemodialysis } \\
\text { Captopril } \\
\text { Nicardipine }\end{array}$ & $\begin{array}{l}\text { Hemodialysis } \\
\text { Nicardipine } \\
\text { Bisoprolol } \\
\text { Frusemide }\end{array}$ \\
\hline $\begin{array}{l}\text { Long term } \\
\text { treatment }\end{array}$ & Output dialysis & Transfer in peritoneal dialysis & $\begin{array}{l}\text { Hemodialysis } \\
\text { Nicardipine } \\
\text { Frusemide } \\
\text { Captopril }\end{array}$ & Hemodialysis \\
\hline Outcome & Partial recovery & Death of unknown cause & $\begin{array}{l}\text { Death by cardiorespiratory } \\
\text { arrest }\end{array}$ & $\begin{array}{l}\text { Chronic hemodialysis on } \\
\text { arteriovenous fistula }\end{array}$ \\
\hline
\end{tabular}

Table 2: Treatment and outcome.

high LDH. In two of our patients, we found a high LDH to 2 times and 8 times the normal associated with thrombocytopenia in the second case. In addition, there is often a microscopic hematuria rarely macroscopic non-selective proteinuria, and leukocyturia and cylindruria [8]. In our study, proteinuria was measured in 3 patients and was elevated in 2 cases 1 and 3 .

Renal imaging may be useful in providing arguments for cortical necrosis and giving an assessment of the extent of damage. The definitive diagnosis of cortical necrosis certainly falls of histological study of renal tissue obtained by renal biopsy, but when the realization of the latter is difficult or even impossible, imaging, particularly computed tomography $\mathrm{CT}$ and magnetic resonance imaging MRI is a great contribution to confirm the diagnosis $[12,13]$. Simple renal ultrasound without injection is systematic in any AKI. It shows normalsized kidneys or increased with a variable differentiation. In our series, kidney size was normal for all our patients but the differentiation was poor in 3 cases case 1, 4 and 5 and normal in the other 2 cases case 2 and 3 (Figure 2).

There is no doubt that renal biopsy is the "gold standard" in the diagnosis of cortical necrosis. In a review of the literature, 95 to $100 \%$ of diagnosis of cortical necrosis in France and India based on histological examination [14]. However, this rate has declined since 1980 from $86 \%$ showing the decline of the dependence of the renal biopsy, since the development of other non-invasive diagnostic methods. These methods have been developed to confirm the cortical necrosis, when the renal biopsy was at risk or contraindicated, because of the instability of the patients or the presence of coagulopathy. Histopathological lesions are varied. However, cortical necrosis affects all components kidney. In the complete form, there is a total destruction of the renal parenchyma leaving intact only small subcapsular and deep areas of the 


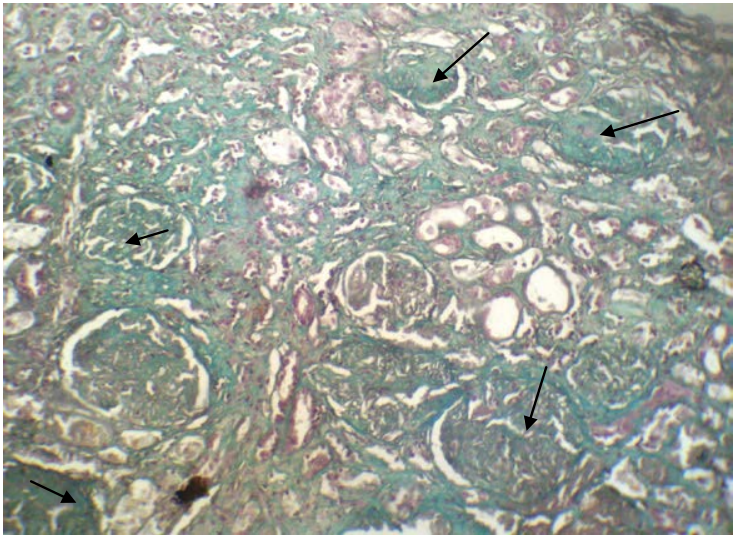

Figure 1: Complete cortical renal necrosis (black arrow).
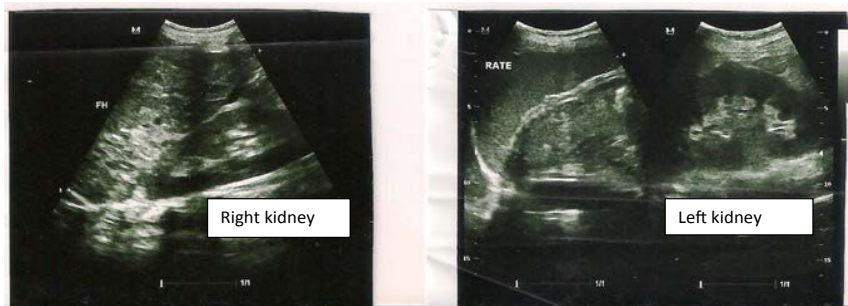

Figure 2: Normal size kidney.

kidney tissue. In this case, kidney failure is irreversible. In the localized form, there is on the same sampling necrotic lesions adjacent normal renal parenchyma. In our cases, cortical necrosis was divided into two groups according to histological criteria: complete cortical necrosis and patchy cortical necrosis. Three of 5 patients had patchy cortical necrosis cases 1,2 and 4 and 2 had a total cortical necrosis cases 3 and 5. This predominance of patchy cortical necrosis was found by Syed in $75 \%$ of cases [15]. In our series, the tubulointerstitial lesions were consistent with type of interstitial fibrosis, tubular necrosis with a case of "tubular ghosts" case 5. These lesions have also been reported by two other authors $[16,17]$. The presence of calcification in the renal cortex as a result of cortical necrosis was found early on biopsy but very late on radiology in one study [18]. There were none in our series. Obstetric causes account for more than half the cases of cortical necrosis 50 to70 \% $[16,17,19]$. It may be secondary to placental abruption, septic abortion, eclampsia, postpartum hemorrhage, amniotic fluid embolism and puerperal sepsis [20]. Septic abortion continues to be a major cause of cortical necrosis, possibly due to endotoxin -mediated endothelial damage leading to vascular thrombosis and subsequent renal ischemia. However, cortical necrosis secondary to septic abortion rare in developed countries is still common in India, between $61.53 \%$ and $78 \%$ $[4,19]$. In our series, postpartum hemorrhage by placental abruption represented $80 \%$ of the cases 4 cases. In two cases, the complicated preeclampsia cases 3 and 5 . In other studies, placental abruption was the main etiology with respectively $50 \%$ and $66.7 \%$ [10,21]. In the study of Sheehan et al, $55 \%$ of fatal cases of placental abruption were associated with cortical necrosis [21]. The preeclamspia and its complications can cause cortical necrosis [15]. Eclampsia was the most common cause in a study in Morocco [9], whereas it was present in $12.5 \%$ of cases Chugh et al. [4]. Two of our patients had preeclampsia [22,23].

The treatment aims to alleviate hemodilution, metabolic disorders, high blood pressure, anemia and infections associated. The iterative hemodialysis should be initiated early in the prevention of metabolic disorders [17]. Several treatments have been tried under etiopathogenic and sometimes associated. This is heparin, fibrinolytic, antiplatelet agents and fresh plasma. These treatments have allowed a partial recovery of renal function in some patients $[17,21]$. However, any curative effect of these treatments on histological lesions was not been proven. These sessions were started in one time less than or equal to 3 days for 3 patients, unlike the other two who started hemodialysis 18 and 32 days after birth. This delay was due to the time reference of the patients in Nephrology department relatively long, respectively 12 and 31 days. In the early 19 s, reported mortality of cortical necrosis was $84 \%$ [1]. In our series one patient partially recovered her renal function but the others progressed rapidly to end-stage renal disease. Among those who entered hemodialysis, two died and one had to stop the treatment because of inaccessibility of medical care.

\section{Conclusion}

Obstetric CRN, still common in developing countries, must remain a rare complication of pregnancy. The best treatment is prevention. The disappearances of clandestine abortions, improving prenatal care and the best care for obstetric complications have resulted in a dramatic decrease in obstetric IRA in developed countries. Antenatal care would detect patients at risk for better prevention.

\section{References}

1. Rinker JR, Thurmond JW (1946) Postpartum, bilateral cortical necrosis of the kidneys with recovery. Am J Surg 72: 286-288.

2. Berland Y, Dussol B (2000) La nÃcrose corticale. NÃphrologie pour linterne. Paris: Elsevier SAS 5P.

3. Prakash J, Rubina V, Wani IA, Murthy AS, Srivasta PK, et al. (2007) Decreasing incidence of renal cortical necrosis in patients with acute renal failure in developing countries; a single-centre experience of 22 years from Eastern India. Nephrol Dial Transplant 22: 1212-1217.

4. Chugh KS, Jha V, Sakhuja V, Joshi K (1994) Acute renal cortical necrosis--a study of 113 patients. Ren Fail 16: 37-47.

5. Prakash J (2012) The kidney in pregnancy: A journey of three decades. Indian J Nephrol 22: 159-167.

6. Tall OL (2011) Contribution $\tilde{A}$ lâÃtude de lâinsuffisance rnale aigue du postpartum. A propos de 146 cas colligÃ@s Ã Dakar. ThÃ"se med. Dakar NÂ162.

7. Costa De Beauregard MA (2001) Obstetrical acute renal failure: a public health problem in developing countries. Nephrologie 22: 3-4.

8. Mhibik S, Barrouch S, Karoui C (2008) Insuffisance rnale aigu secondaire A une ncrose corticale: $\tilde{A}$ propos de 8 cas. Rev med interne 29: 337-S411.

9. Miguil M, Salmi S, Moussaid I, Benyounes R (2011) Acute renal failure requiring haemodialysis in obstetrics. Nephrol Ther 7: 178-181.

10. MacGillivray I (1951) Bilateral renal cortical necrosis in obstetric practice. J Obstet Gynaecol Br Emp 58: 92-100.

11. MacGillivray I (1951) Bilateral renal cortical necrosis in obstetric practice. J Obstet Gynaecol Br Emp 58: 92-100.

12. François M, Tostivint I, Mercadal L, Bellin MF, Izzedine $H$, et al. (2000) MR imaging features of acute bilateral renal cortical necrosis. Am J Kidney Dis 35: 745-748.

13. Jha V, Sakhuja V (2005) Postpartum renal cortical necrosis. Nephrol Dial Transplant 20: 1010

14. Kim HJ (1995) Bilateral renal cortical necrosis with the changes in clinical features over the past 15 years (1980-1995). J Korean Med Sci 10: 132-141.

15. Sural S, Panja C (2012) Acute renal failure in pregnancy. Clinical Queries: Nephrology 1: 99-102. 
Citation: Cisse MM, Ka EF, Seck SM, Dial CM, Diouf AA, et al. (2014) Obstetric Cortical Renal Necrosis, Even Reality in the Tropics. J Nephrol Ther 4: 156. doi:10.4172/2161-0959.1000156

Page 4 of 4

16. Lauler DP, Schreiner GE (1958) Bilateral renal cortical necrosis. Am J Med 24: 519-529.

17. Matlin RA, Gary NE (1974) Acute cortical necrosis. Case report and review of the literature. Am J Med 56: 110-118.

18. Walls J, Schorr WJ, Kerr DN (1968) Prolonged oliguria with survival in acute bilateral cortical necrosis. Br Med J 4: 220-222.

19. Goplani KR, Shah PR, Gera DN, Gumber M, Dabhi M, et al. (2008) Pregnancyrelated acute renal failure: A single-center experience. Indian J Nephrol 18: $17-21$

20. Ali SS, Rizvi SZ, Muzaffar S, Ahmad A, Ali A, et al. (2003) Renal cortical necrosis: a case series of nine patients \& review of literature. J Ayub Med Coll Abbottabad 15: 41-44.

21. Hiault C, Dequiedt P, Benoit O, Dognin C, Monnier JC, et al. (1982) Postpartum renal cortical necrosis. J Gynecol Obstet Biol Reprod (Paris) 11: 839-848.

22. Ansari MR, Laghari MS, Solangi KB (2008) Acute renal failure in pregnancy: one year observational study at Liaquat University Hospital, Hyderabad. J Pak Med Assoc 58: 61-64.

23. Belenfant X, Pallot JL, Reziz K (2004) Insuffisance rÃ@nale aiguÃ et grossesse. E.M.C Ã@phrologie. Paris: Elsevier-Masson. Mise Ã jour en 18-059-L-10, 7P. 